\title{
A Study of Benefits and Services in MSN Pharmaceutical Company Hyderabad
}

\author{
Dr. D.M. Sheaba Rani ${ }^{1}$, G. Sri Ranjith ${ }^{2}$, K. Venkatarattaiah ${ }^{3}$ \\ ${ }^{1}$ (Professor, Department of Commerce and Management Studies, Andhra University, Visakhapatnam-530003, \\ Andhra Pradesh-India) \\ ${ }_{2}^{2}$ Full Time Research Scholar, Department of Commerce and Management Studies, Andhra University, \\ Visakhapatnam-530003, Andhra Pradesh-India) \\ ${ }_{3}^{3}$ Full Time Research Scholar, Department of Commerce and Management Studies, Andhra University, \\ Visakhapatnam-530003, Andhra Pradesh-India)
}

\begin{abstract}
:
Purpose- This paper is an attempt to examine and identify the importance of benefits and services provided by the MSN Pharmaceutical Company to the employees and the employees' satisfaction on the above factors.

Design/Methodology/Approaches- The data were taken from 380 employees who were placed in different departments of the company. Fringe benefits and other benefits and services are measured by Kruskal Wallis Test and Mann Whitney-U Test.

Findings- According to Kruskal Wallis Test-it is implicit that the dimensions fringe benefits and other benefits and services in relation to departments are found to be significant. This difference may be due to various types of departments exist in the company. The mean ranks among the three cadres of the respondents are statistically significant for the dimensions fringe benefits and other benefits and services.

Mann-Whitney-U Statistic Test for the dimension fringe benefits and other benefits and services are statistically significant i.e., whatever may be the gender the response given by them is not similar to each others.

There is a significant mean difference in the opinion score between the unmarried and married respondents in relation to fringe benefits. Marital status has no impact on their opinion on the dimension other benefits and services.
\end{abstract}

Keywords Benefits, Department, Fringe benefit, Gender, Services

\section{Prologue}

The employer though not bound, provides several benefits and services to the employees working in the organization to maintain and promote the employees' favourable attitude towards the work and work environment, because maintenance of favourable attitude towards the work is an essential part of motivation and high morale. Such benefits and services, being a part of wage and salary administration, include all expenditure incurred to benefit employees over and above regular wages and direct monetary incentives related to output and are generally referred to as fringe benefits. The real wages of workers are increased by the benefits provided by the employer and thus, they are regarded as supplement to their wages. Many years ago, benefits and services were labeled 'fringe' benefits because they were relatively insignificant or fringe components of compensation. However, the situation now is different, as these have, more or less, become important part of a comprehensive compensation package offered by employers to employees.

Employee benefits and services are any benefits that the employee receives in addition to direct remuneration Benefits and services however are indirect compensation because they are usually extended as a condition of employment and are not directly related to performance' These benefit programs must be managed carefully to enhance recruitment and to boost the morale of the employees Benefits and compensation provided to the employees usually depend on the conditions of employment and other factors like security, safety, health, welfare and recreation of employees

These are provided at the discretion of the management with consultation with the trade unions. These services are provided at low or no cost to the employee. In addition to fringe benefits, organizations also provide services that employees find desirable. Employee services include, services related to type of work performedincludes subsidies for the purchase and upkeep of work clothing and uniform. Eating facilities, Transportation facilities, Child care facilities, Housing services, Financial and legal services, Recreational, Cultural and social programs, Educational services, Medical services, Outplacement services, Flexible time, Cafeteria service.

\subsection{Objective}

1. To assess the benefits and services provided by the MSN Pharmaceutical company 


\subsection{Research Hypotheses}

I. Kruskal Wallis test

1. The demographic variables department, cadre, age and education have no impact on the dimensions related to fringe benefits and other benefits and services.

II. Mann-Whitney U-statistic test

1. There is no significant difference in the opinion of the respondents regarding gender and marital status related to fringe benefits and other benefits and services.

\subsection{Research Methodology}

Population and sample

The target population of this study was the employees of Manna Satyanarayana Laboratories, Hyderabad. All the departments in the company were covered in the survey. These all departments were stratified into seven departments. Sample was drawn from each department proportionate to the population, approximately 11 per cent is taken as per convenience. Survey questionnaire was used as an instrument to collect primary data. The questionnaire was divided into two sections Section-A Benefits and Section-B Services. Section-A deals with questions related to fringe benefits, bonus payment, incentives, advance payment, purpose of advance, respondents opinion on benefits etc., Section-B has questions relating to accident compensation, medical insurance, medical reimbursement, transport facility, functioning of canteen, respondents opinion on other benefits and services etc. The researchers took 380 employees as the sample size for the present study. For data collection the statistical techniques used are stratified sampling, proportioned sampling and simple random sampling. The primary data have been interpreted with the help of simple statistical tools such as simple percentages, ranking method, Kruskal Wallis Statistical test was carried forward for the dimensions like fringe benefits and other benefits and services with regard to department, cadre, age and educational background. Further for these dimensions, Mann-Whitney U-Statistic Test was steered with regard to gender and marital status.

\section{A. Benefits}

\section{Analysis and Discussion}

\subsection{Opinion on fringe benefits}

Fringe benefits are benefits which supplements the employees' ordinary wages and which is of value to them and their families in so far as it materially increases their retirement benefits. According to the Glossary of Industrial Relations and Wage Terms "Fringe benefits are supplements to wages received by workers at a cost to the employers. The term encompasses a number of benefits-paid vacation, pension, health insurance plans, etc. which usually add up to something more than a 'fringe' and is sometimes applied to a practice that may constitute a dubious benefit for workers ${ }^{1}$."

Table No.2.1: Respondents' opinion on providing any fringe benefits in addition to wages

\begin{tabular}{|l|c|c|}
\hline Opinion & Frequency & Per cent \\
\hline Yes & 357 & 93.9 \\
\hline No & 23 & 6.1 \\
\hline Total & 380 & 100.0 \\
\hline
\end{tabular}

Respondents' opinion on providing any fringe benefits in addition to wages is illustrated in table no.2.1. A vast majority of 357 respondents equalling to 93.9 per cent revealed that they are getting fringe benefits in addition to their salary. The remaining 23 respondents equalling to 6.1 per cent revealed that they are not getting any fringe benefits. It is a healthy sign that the management is providing fringe benefits to their employees to motivate them to work hard. The 23 respondents who are on temporary basis will not be provided with fringe benefits. They are provided with one or two benefits like canteen facility etc.

\subsection{Opinion on fringe benefits provided by the employer}

Table No.2.2: Respondents' opinion on fringe benefits provided by employer

\begin{tabular}{|l|c|c|}
\hline \multicolumn{1}{|c|}{ Wage benefits } & Yes & No \\
\hline Bonus /bakshis & $373(98.2 \%)$ & $7(1.8 \%)$ \\
\hline Leave with pay & $285(75 \%)$ & $95(25 \%)$ \\
\hline Medical benefits & $372(97.9 \%)$ & $8(2.1 \%)$ \\
\hline Maternity benefits & $354(93.2 \%)$ & $26(6.8 \%)$ \\
\hline Rate concession in purchase of medicines for personal use & $18(4.7 \%)$ & $362(95.3 \%)$ \\
\hline Accident benefit & $224(58.9 \%)$ & $156(41.1 \%)$ \\
\hline Transport facility & $170(44.7 \%)$ & $210(55.3 \%)$ \\
\hline Uniform allowance & $27(7.1 \%)$ & $353(92.9 \%)$ \\
\hline House rent allowance & $269(70.8 \%)$ & $111(29.2 \%)$ \\
\hline Any other & $87(22.9 \%)$ & $293(77.1 \%)$ \\
\hline
\end{tabular}


Respondents' opinion on fringe benefits provided by the employer is depicted in table no.2.2. Bonus/bakshis is a major fringe benefit given to the respondents 98.2 per cent followed by medical benefit 97.9 per cent, maternity benefit 93.2 per cent, leave with pay 75 per cent, house rent allowance 70.8 per cent, accident benefit 58.9 per cent and transport 44.7 per cent. On the other hand dress allowance 7.1 per cent and rate concession in purchase of medicines for personal use 4.7 per cent are observed to be the less wage supplements extended to the respondents.

Thus, it can be concluded that the majority of the respondents are getting different benefits from their employer, whereas respondents are not given dress allowance and concession in purchase of medicines for personal use. So it is suggested to the management to provide dress allowance and rate concession in purchase of medicines for personal use, which may give more relief to the respondents.

\subsection{Fringe benefits improve the productivity}

Table No.2.3: Fringe benefits improve the employees productivity

\begin{tabular}{|l|c|c|}
\hline Opinion & Frequency & Per cent \\
\hline Yes & 125 & 32.9 \\
\hline No & 255 & 67.1 \\
\hline Total & 380 & 100.0 \\
\hline
\end{tabular}

Respondents opinion on fringe benefits improve the productivity of employees is described in table no.2.3. Out of 380 respondents (67.1\%) equalling to 255 respondents revealed that fringe benefits given to them are not contributing for increased productivity. Whereas the balance 125 respondents (32.9\%) told that fringe benefits are improving employee productivity.

From the above table it can be concluded that the MSN company authorities are providing fringe benefits but the employees are not satisfied with the fringe benefits provided to them. It is suggested to the management to increase the number of fringe benefits in order to motivate the employee to increase the productivity of the company.

\subsection{Opinion on bonus payment}

A bonus is an additional compensation given to an employee above his/her normal wage. A bonus can be used as a reward for achieving specific goals set by the company, or for dedication to the company.

Table No.2.4: Respondents' opinion on bonus payment

\begin{tabular}{|l|c|c|}
\hline Opinion & Frequency & Per cent \\
\hline Regularly & 335 & 88.2 \\
\hline Now and then & 45 & 11.8 \\
\hline Total & 380 & 100.0 \\
\hline
\end{tabular}

Table no.2.4 reveals the opinion of the respondents regarding bonus payment. A whopping majority of 335 respondents equalling to 88.2 per cent revealed that bonus is paid regularly by their employer. Whereas 45 respondents equalling to 11.8 per cent of them revealed that bonus is paid now and then. At the outset it is happy to note that all the respondents are receiving bonus from their employer.

\subsection{Basis for payment of bonus}

Table No.2.5: Basis for payment of bonus

\begin{tabular}{|l|c|c|}
\hline Basis & Frequency & Per cent \\
\hline Strictly based on profits & 158 & 41.6 \\
\hline Fixed amount irrespective of profits & 203 & 53.4 \\
\hline Purely at employer discretion & 19 & 5.0 \\
\hline Total & 380 & 100.0 \\
\hline
\end{tabular}

Table no.2.5 reveals about the basis for the payment of bonus. About 53.4 per cent of the total sample respondents opined that fixed amount is paid irrespective of profits as bonus to them. According to 41.6 per cent of the respondents' opinion that the bonus is paid strictly based on profits. A negligible 5 per cent of the respondents revealed that the bonus is paid purely at employer discretion.

It is a good sign to note that employer discretion for payment of bonus is not given much importance which means that employer is not using his own decision for payment of bonus.

\subsection{Incentives provided to the employees}

A dictionary definition of an incentive is 'something that motivates you to do something'. In economics one can say that an incentive is a benefit, reward, or cost that motivates an economic action. 
Table No.2.6: Incentives provided to the employees

\begin{tabular}{|l|c|c|}
\hline Opinion & Frequency & Per cent \\
\hline Yes & 98 & 25.8 \\
\hline No & 282 & 74.2 \\
\hline Total & 380 & 100.0 \\
\hline
\end{tabular}

Respondents' opinion on incentives provided to them is described in table no.2.6. A vast majority of 74.2 per cent of the respondents revealed that they are not paid any incentives to them. The remaining 25.8 per cent of the total sample respondents told that they are provided with incentives.

The above table concludes that majority of the respondents are not provided with incentives. This attitude of the management may demotivate the employees to work hard. It is suggested to the MSN authorities to provide incentives to majority of the employees, so that the employees may be motivated to work hard and improve the productivity. Cash incentive may motivate the worker to improve his performance which in turn increases the productivity of the organization.

\subsection{Method of payment for incentives}

Table No.2.7: Method of payment for incentives

\begin{tabular}{|l|c|c|}
\hline Mode & Frequency & Per cent \\
\hline Cash & 48 & 49.0 \\
\hline Kind & 44 & 44.9 \\
\hline Both & 6 & 6.1 \\
\hline Total & 98 & 100.0 \\
\hline
\end{tabular}

Method of payment for incentives is shown in table no: 2.7. The different methods used for incentives payment are (i) cash (ii) kind (iii) both. The 98 respondents who have received incentives are scattered among these three methods. About 49 per cent of them are receiving cash, 44.9 per cent are receiving kind and the balance 6.1 per cent of the respondents is receiving both cash and kind.

\subsection{Advance payment of wage received by the respondents}

Taking advance from the employer to meet emergencies and unforeseen contingencies is not uncommon. Such advances are usually recovered from the salaries of the employees.

Table No.2.8: Advance payment of wage received by the respondents

\begin{tabular}{|l|c|c|}
\hline Opinion & Frequency & Per cent \\
\hline Yes & 261 & 68.7 \\
\hline No & 119 & 31.3 \\
\hline Total & 380 & 100.0 \\
\hline
\end{tabular}

It is observed that the earnings of the respondents are inadequate and consequently they are taking advances from the employees. Table no: 2.8 gives the information of advance payments received by the respondents. A majority of 68.7 per cent of the total sample respondents revealed that they are given advances by their employer. The remaining 31.3 per cent of the respondents told they are not given any advance by their employer.

The above table concludes that the management is generous in giving advance payments to their employees. But some employees are not receiving any advance, so it is suggested to the management to provide some advance to the remaining 119 respondents.

\subsection{Purpose for which advance is required by the employees}

Table No.2.9: Purpose for which advance is required by the employees

\begin{tabular}{|l|c|c|c|c|c|c|}
\hline Purpose & $\mathbf{1}$ & $\mathbf{2}$ & $\mathbf{3}$ & $\mathbf{4}$ & $\mathbf{5}$ & Weight Rank \\
\hline Consumption & $7(35)$ & $48(192)$ & $81(243)$ & $47(94)$ & $78(78)$ & $642(3)$ \\
\hline Children's education & $156(780)$ & $67(268)$ & $33(99)$ & $4(8)$ & $1(1)$ & $1156(1)$ \\
\hline Medical & $84(420)$ & $118(472)$ & $38(114)$ & $13(26)$ & $8(8)$ & $1040(2)$ \\
\hline Social and religious purpose & $6(30)$ & $23(92)$ & $67(201)$ & $72(144)$ & $93(93)$ & $560(4)$ \\
\hline Entertainment & $8(40)$ & $5(20)$ & $36(108)$ & $137(274)$ & $75(75)$ & $517(5)$ \\
\hline
\end{tabular}

Generally the earnings of the employees in private sector are inadequate and consequently they are taking advances from the employer. The researcher asked the 261 respondents who took advances from the employer regarding the purpose for taking the advance. Majority of the employees took loan or advances for their children's education which ranked first with 1156 score. Second rank is recorded to medical with 1040 score, third rank is given to consumption with 642 score, fourth rank to social and religious purpose with 560 score and last rank to entertainment with 517 score. 
Now a days due to high cost of living, high education and medical expenses most of the respondents are taking advances to meet the above needs. As such children education, medical and consumption are the major purposes for which advances is required by the employees. Advances taken for social and religious purpose and entertainment are insignificant. (table no.2.9)

\subsection{Respondents opinion on benefits}

Table No.2.10: Respondents' opinion on benefits

\begin{tabular}{|l|c|c|}
\hline Opinion & Frequency & Per cent \\
\hline Adequate & 269 & 70.8 \\
\hline Inadequate & 20 & 5.3 \\
\hline No opinion & 91 & 23.9 \\
\hline Total & 380 & 100.0 \\
\hline
\end{tabular}

Respondents' opinion on benefits is portrayed in table no.2.10. A vast majority of 70.8 per cent of the total sample respondents revealed that the benefits given to them are adequate, 23.9 per cent of them told no opinion. A small per cent of 5.3 of the respondents opined that the benefits given to them are inadequate.

It may be concluded that a considerable number of 91 respondents gave no opinion on the benefits given to them by the employer. It is suggested to the management to concentrate on these employees to change their opinion.

\section{B. Services}

\subsection{Opinion on accident compensation}

Workers' compensation law is governed by statutes in every state. Specific laws vary with each jurisdiction, but key features are consistent. An employee is automatically entitled to receive certain benefits when he or she suffers an occupational disease or accidental personal injury arising out of and in the course of employment. Such benefits may include cash or wage loss benefits, medical and career rehabilitation benefits, and in the case of accidental death of an employee, benefits to dependents. The Negligence and fault of either the employer or the employee usually are immaterial. Independent contractors are not entitled to workers' compensation benefits, and in some states domestic workers and agricultural workers are excluded or only partially covered.

Table No.2.11: Respondent' opinion on accident compensation

\begin{tabular}{|l|c|c|}
\hline Opinion & Frequency & Per cent \\
\hline Adequate & 147 & 38.6 \\
\hline Paid in time & 183 & 48.2 \\
\hline Payment delayed & 6 & 1.6 \\
\hline No opinion & 44 & 11.6 \\
\hline Total & 380 & 100.0 \\
\hline
\end{tabular}

Respondents' opinion on accident compensation is given in table no.2.11. About 48.2 per cent of the respondents revealed that the accident compensation is paid in time, 38.6 per cent of the respondents opined adequate accident compensation, where as 11.6 per cent of the respondents revealed no opinion and a minute per cent of 1.6 of them told accident compensation payment is delayed. The above table concludes that a majority of 86.8 per cent of the respondents are happy regarding accident compensation.

\subsection{Respondents covered by medical insurance}

Table No.2.12: Respondents covered by medical insurance

\begin{tabular}{|l|c|c|}
\hline Opinion & Frequency & Per cent \\
\hline Yes & 380 & 100.0 \\
\hline
\end{tabular}

Respondents' opinion on the medical insurance coverage is shown in table no.2.12. All the 380 total sample respondents are covered by medical insurance. The MSN management is so generous in providing medical insurance to all the employees whether permanent or temporary.

\subsection{Opinion on the type of medical insurance}

Table No.2.13: Respondents' opinion on type of medical insurance

\begin{tabular}{|l|c|c|}
\hline Type & Frequency & Per cent \\
\hline Medi-claim & 380 & 380 \\
\hline Total & 380 & 100.0 \\
\hline
\end{tabular}

Respondents' opinion on the type of medical insurance is noted in table no.2.13. The researcher asked about the different types of medical insurance schemes like (i) medi-claim (ii) ESI (iii) others. All the 380 total sample respondents are covered under medi-claim scheme. 


\subsection{Extent of medical reimbursement}

MERP (Medical Expense Reimbursement Plans) Plans are sanctioned under Section 105 of the IRC. A MERP is a type of Health Reimbursement Arrangement (HRA) that enables employers to fund portions of their employees' health plan deductibles, coinsurance, or copayments, as well as, cover the cost of other qualified medical expenses on a tax-free basis. MERP Plans are commonly utilized with higher deductible plan designs, giving the employer the flexibility to create any plan design they would like. By purchasing a higher deductible health plan, an employer and their employees can benefit from the premium savings, but utilizing the MERP allows the employer to continue offering a quality benefit package to employees.

MERP plans are a great step for an employer to start controlling their health plan costs year after year. When entering into a MERP Plan arrangement, the typical scenario is to realize a great deal of savings in the first year of implementation and the goal in future years is to continue stabilizing that cost each renewal. There is no physical account linked to a MERP Plan, like there may be with an HRA, the employer only reimburses for expenses after they have been incurred.

Table No.2.14: Extent of medical reimbursement

\begin{tabular}{|l|c|c|}
\hline Reimbursement & Frequency & Per cent \\
\hline Rs 0-10,000 & 11 & 2.9 \\
\hline Rs 10,001-20,000 & 49 & 12.9 \\
\hline Rs 20,001-30,000 & 88 & 23.1 \\
\hline Rs 30,001-40,000 & 99 & 26.1 \\
\hline Rs Above 40,000 & 133 & 35.0 \\
\hline Total & 380 & 100.0 \\
\hline
\end{tabular}

The opinion of the respondents on the extent of medical reimbursement is provided by five class intervals such as (i) Rs. 0-10,000 (ii) Rs. 10,001-20,000 (iii) Rs. 20,001-30,000 (iv)Rs. 30,001-40,000 (v) Above Rs. 40,000. About 35 per cent of the total sample respondents are receiving above Rs 40,000 as medical reimbursement followed by 26.1 per cent of the respondents placed in between Rs.30, 001-40,000, and 23.1 per cent of them are recorded in between the class interval of Rs 20,001-30,000. About 12.9 per cent of the respondents are placed in between Rs. 10,001-20,000, where as a small per cent of 2.9 are receiving below Rs. 10,000 as medical reimbursement. The above table concluded that all the 380 respondents are receiving medical reimbursement to lead their life happily. (table.no.2.14)

\subsection{Availing the facility of housing loan}

Table No.2.15: Respondents' availing the facility of housing loan

\begin{tabular}{|l|c|c|}
\hline Opinion & Frequency & Per cent \\
\hline No & 380 & 100.0 \\
\hline
\end{tabular}

Respondent's opinion on housing loan facility is portrayed in table no.2.15. It is unfortunate to note that all the 380 total sample respondents are not given housing loans. This shows that the management is not encouraging to give housing loans to their employees. House is a bare necessity to the employees to live comfortably and lead a happy life. So, it is suggested to the management to provide some housing loans to their employees to purchase a comfortable house.

\subsection{Opinion on transport facility}

The company is providing buses to the employees for their travel from residence to company. This transport facility is provided to some areas in Hyderabad city.

Table No.2.16: Respondents' opinion on transport facility

\begin{tabular}{|l|c|c|}
\hline Opinion & Frequency & Per cent \\
\hline Adequate & 219 & 57.6 \\
\hline Inadequate & 19 & 5.0 \\
\hline No opinion & 142 & 37.4 \\
\hline Total & 380 & 100.0 \\
\hline
\end{tabular}

Respondents' opinion on transport facility is presented in table no.2.16. About 219 respondents equalling to 57.6 per cent opined adequate opinion on transport facility, whereas 142 respondents equalling to 37.4 per cent of them had no opinion on transport facility. About 19 respondents equalling to 5 per cent revealed inadequate opinion on transport facility. The MSN management is providing own buses as a transport facility to the employees, for some areas as such a some of respondents are happy with the transport facility. This transport facility may boost the morale of the respondents to work hard. On the other hand the management has to concentrate on 142 respondents who had no opinion on transport facility. 


\subsection{Opinion on the functioning of canteen}

Table No.2.17: Respondents 'opinion on the functioning of canteen

\begin{tabular}{|l|c|c|}
\hline Opinion & Frequency & Per cent \\
\hline Satisfactory & 247 & 65.0 \\
\hline Poor & 42 & 11.1 \\
\hline No opinion & 91 & 23.9 \\
\hline Total & 380 & 100.0 \\
\hline
\end{tabular}

Respondent's opinion on the functioning of canteen is noted in table no.2.17. A highest majority of 65 per cent of the respondents revealed satisfactory opinion on canteen functioning, where as 23.9 per cent of the respondents had no opinion on the functioning of canteen. About 11.1 per cent of the respondents revealed poor maintenance of canteen. MSN authorities are providing subsidise rates for the items sold in canteen. The subsidise rates help the employees to save some money for that reason majority of the respondents are happy with canteen facility provided by the management.

\subsection{Opinion on the other benefits and services provided to them}

Employee benefits and services are any benefits that the employee receives in addition to direct remuneration 'Fringes embrace a broad range of benefits and services that employees receive as part of their total package. It is based on critical job factors and performance. Benefits and services however are indirect compensation because they are usually extended as a condition of employment and are not directly related to performance'. Benefits and compensation provided to the employees usually depend on the conditions of employment and other factors like security, safety, health, welfare and recreation of employees. These benefit programs must be managed carefully to enhance recruitment and to boost the morale of the employees

Table No.2.18: Respondents' opinion on the other benefits \& services provided to them

\begin{tabular}{|l|c|c|c|}
\hline Benefits \&services & Satisfy & Satisfied to some extent & Not satisfy \\
\hline Canteen & $247(65 \%)$ & $74(19.5)$ & $59(15.5)$ \\
\hline Lunch Room & $273(71.8)$ & $101(26.6)$ & $6(1.6)$ \\
\hline Medical Facilities & $302(79.5)$ & $78(20.5)$ & $2(0.5)$ \\
\hline Washing facilities & $289(76.1)$ & $89(23.4)$ & \\
\hline Supply of drinking water & $328(86.3)$ & $52(13.7)$ & $7(1.9)$ \\
\hline Facilities for storing \& drying of clothes & $219(57.6)$ & $154(40.5)$ & $5(1.3)$ \\
\hline Provident fund scheme & $241(63.4)$ & $139(36.6)$ & $72(18.9)$ \\
\hline Payment of gratuity & $209(55)$ & $166(43.7)$ & $255(67.1)$ \\
\hline Leave with pay & $248(65.3)$ & $60(15.8)$ & $380(100)$ \\
\hline Workmen's compensation & $62(16.3)$ & $63(16.6)$ & $46(12.1)$ \\
\hline Housing facilities & 0 & 0 & $358(94.2)$ \\
\hline Transport & $126(33.2)$ & $208(54.7)$ & $35(93.4)$ \\
\hline Facilities for education of employees children & $9(2.4)$ & $13(3.4)$ & $363(95.5)$ \\
\hline Leave travel concession & $13(3.4)$ & $12(3.2)$ & $311(81.8)$ \\
\hline Recreational facilities & $4(1.1)$ & $13(3.4)$ & \\
\hline Uniform & $3(0.8)$ & $66(17.4)$ & $368(96.8)$ \\
\hline Community welfare measures & $13(3.4)$ & $367(96.6)$ & $365(96.1)$ \\
\hline Co-operation society & & $12(3.2)$ & $284(74.7)$ \\
\hline Funeral expenses & $3(0.7)$ & $12(3.2)$ & \\
\hline Advance for marriage of family members & $20(5.3)$ & $76(20)$ & \\
\hline
\end{tabular}

Respondents' opinion on the benefits and services provided to them is furnished in table no.2.18. About 86.3 per cent of the respondents are satisfied with the supply of drinking water provided by the company and the balance 13.7 per cent are satisfied to some extent. Regarding medical facilities 79.5 per cent of them are satisfied and the balance 20.5 per cent is satisfied to some extent. As far as washing facilities are concerned 76.1 per cent of the respondents are satisfied, 23.4 per cent are satisfied to some extent and 0.5 per cent are not satisfied. Regarding lunch room 71.8 per cent of the respondents are satisfied, 26.6 per cent are satisfied to some extent and 1.6 per cent opined dissatisfaction. About leave with pay 65.3 per cent of the respondents are satisfied, 18.9 per cent are dissatisfaction and 15.8 per cent are satisfied to some extent. Regarding canteen facility, 65 per cent of the respondents are satisfied, 19.5 per cent are satisfied to some extent and 15.5 per cent opined dissatisfaction. As far as provident fund scheme is concerned 63.4 per cent of the respondents are satisfied and the remaining 36.6 per cent are satisfied to some extent. For facilities like storing and drying of clothes about 57.6 per cent of the respondents' opined satisfaction, 40.5 per cent are satisfied to some extent and 1.9 per cent opined dissatisfaction. For payment of gratuity 55 per cent of the respondents are satisfied, 43.7 per cent are satisfied to some extent and 1.3 per cent are not satisfied. Regarding transport facility 54.7 per cent of the respondents are satisfied to some extent, 33.2 per cent are satisfied and 12.1 per cent are dissatisfied.

As far as workmen's compensation is concerned, a highest majority of 67.1 per cent of the respondents is not satisfied, 16.6 per cent are satisfied to some extent and 16.3 per cent are satisfied. Advance for marriages 
of family members concerned a vast majority of 74.7 per cent who are dissatisfied, 20 per cent are satisfied to some extent and 5.3 per cent of them are satisfied. Regarding leave travel concession a whopping majority of 93.4 per cent of the respondents are dissatisfied, 3.4 per cent are satisfied and 3.2 per cent are satisfied to some extent. About community welfare measures a highest majority of 96.6 per cent of the respondents are satisfied to some extent and the balance 3.4 per cent of them are satisfied. Regarding funeral expenses a vast majority of 96.1 per cent of the total sample respondents showed dissatisfaction, 3.2 per cent are satisfied to some extent and 0.7 per cent are satisfied. About uniform facility a majority of 81.8 per cent of them are dissatisfied, 17.4 per cent are satisfied to some extent and 0.8 per cent of the respondents are satisfied. Regarding co-operative society a whopping majority of 96.8 per cent are dissatisfied and the balance 3.2 per cent of them are satisfied to some extent. For recreation facility 95.5 per cent are dissatisfied, 3.4 per cent are satisfied to some extent and 1.1 per cent of them are satisfied. The above table concludes that supply of drinking water, medical facility, washing facility, lunch room, leave with pay, canteen facilities, provident fund etc are adequate. Whereas for cooperative societies, funeral expenses, recreation facilities, children education, leave travel concession, uniform and workman's compensation the respondents opined for maximum dissatisfaction. The level of benefits and services provided by the management may motivate the employees to work hard and increase the productivity of the company. Therefore, it is suggested to the management to improve the above said facilities.

\section{Kruskal Wallis test}

Table No.2.19: Respondents' opinion on fringe benefits and other benefits \& services vs. departments

\begin{tabular}{|c|c|c|c|c|c|c|}
\hline Dimension & Department & $\mathrm{n}$ & Mean Rank & H-Statistic & P-Value & Decision \\
\hline \multirow{7}{*}{$\begin{array}{l}\text { Opinion on } \\
\text { Fringe Benefits }\end{array}$} & Production & 102 & 162.20 & \multirow[t]{7}{*}{41.144} & \multirow[t]{7}{*}{0.000} & \multirow[t]{7}{*}{ Significant } \\
\hline & QA & 65 & 251.21 & & & \\
\hline & $\mathrm{QC}$ & 53 & 215.72 & & & \\
\hline & R\&D Department & 44 & 225.48 & & & \\
\hline & HR \& IT & 31 & 153.79 & & & \\
\hline & $\begin{array}{l}\text { Finance \& Business } \\
\text { Development }\end{array}$ & 39 & 165.13 & & & \\
\hline & Others & 46 & 160.66 & & & \\
\hline \multirow{7}{*}{$\begin{array}{l}\text { Other Benefits } \\
\& \text { Services }\end{array}$} & Production & 102 & 241.23 & \multirow[t]{7}{*}{126.431} & \multirow[t]{7}{*}{0.000} & \multirow[t]{7}{*}{ Significant } \\
\hline & QA & 65 & 256.33 & & & \\
\hline & $\mathrm{QC}$ & 53 & 204.30 & & & \\
\hline & R\&D Department & 44 & 182.84 & & & \\
\hline & HR \& IT & 31 & 267.10 & & & \\
\hline & $\begin{array}{l}\text { Finance \& Business } \\
\text { Development }\end{array}$ & 39 & 149.37 & & & \\
\hline & Others & 46 & 82.89 & & & \\
\hline
\end{tabular}

It is implicit from table no.2.19 that the dimensions fringe benefits and other benefits and services are significant as its P-values 0.00 for both are found to be significant at 0.05 level. This explains the significant difference in the mean opinion score of the respondents of the different departments on these dimensions. This difference may be due to various types of departments exist in the company. The respondents who are working in QA department opined more positively than the remaining departments for fringe benefits with 251.21 score. The benefits given by the company for this department is tremendous when compared with other departments. For the dimension other benefits and services, the HR \& IT departments respondents given more optimistic opinion (267.10) followed by QA (256.33). Least score (149.37) is given by finance and business development.

Table No.2.20: Respondents' opinion on fringe benefits and other benefits \& services vs. cadre

\begin{tabular}{|l|l|l|l|l|l|l|}
\hline Dimension & Cadre & $\mathrm{n}$ & Mean Rank & Chi square & P-Value & Decision \\
\hline \multirow{2}{*}{$\begin{array}{l}\text { Opinion on Fringe } \\
\text { Benefits }\end{array}$} & Executive & 246 & 173.93 & 20.475 & 0.000 & Significant \\
\cline { 2 - 5 } & Functional & 30 & 190.85 & & & \\
\cline { 2 - 5 } & Managerial & 104 & 229.60 & & & \\
\hline \multirow{2}{*}{$\begin{array}{l}\text { Other Benefits \& } \\
\text { Services }\end{array}$} & Executive & 246 & 196.47 & 9.177 & 0.010 & Significant \\
\cline { 2 - 4 } & Functional & 30 & 132.78 & & & \\
\cline { 2 - 4 } & Managerial & 104 & 193.03 & & & \\
\hline
\end{tabular}

From the above table no.2.20 it is concluded that the mean ranks among the three cadres of the respondents are statistically significant for the dimensions fringe benefits and other benefits and services and the $\mathrm{P}$-values are less than 0.05 . For the dimension fringe benefits the opinion of managerial cadre respondents are significantly positive rather than the remaining two cadres. The executive cadre respondents mean rank 196.47 and they opined significantly more positive that the remaining two categories for the dimensions other benefits and services followed by managerial cadre mean rank 193.03 and functional cadre mean rank 132.78. 
Table No.2.21: Respondents' opinion on fringe benefits and other benefits \& services vs. age

\begin{tabular}{|l|l|l|l|l|l|l|}
\hline Dimension & Age & $\mathrm{n}$ & Mean Rank & Chi square & P-Value & Decision \\
\hline \multirow{2}{*}{$\begin{array}{l}\text { Opinion on Fringe } \\
\text { Benefits }\end{array}$} & 20 to 29 Yrs & 157 & 215.61 & 24.0955 & 0.000 & Significant \\
\cline { 2 - 5 } & 30 to 39Yrs & 172 & 161.41 & & & \\
\cline { 2 - 5 } & 40 to 49Yrs & 51 & 211.30 & & & \\
\hline \multirow{2}{*}{$\begin{array}{l}\text { Other Benefits \& } \\
\text { Services }\end{array}$} & 20 to 29 Yrs & 157 & 185.01 & 1.613 & 0.446 & Not Significant \\
\cline { 2 - 4 } & 30 to 39Yrs & 172 & 190.52 & & & \\
\cline { 2 - 4 } & 40 to 49Yrs & 51 & 207.35 & & \\
\hline
\end{tabular}

Respondents opinion on fringe benefits and other benefits and services with regarded to age is given in table no.2.21. As per the opinion of respondents there is a significant mean difference in opinion score between the age groups with respect to the dimension fringe benefits. Where as there is no significant mean difference between the age groups with respect to the dimension other benefit and services.

Further for the dimension fringe benefits the highest mean value is 215.61 for the respondents belonging to the age group of 20-29 years. For the dimension other benefits and services the highest mean value 207.35 is backed by the respondents in the age group of 40-49 years.

Table No.2.22: Respondents' opinion on fringe benefits and other benefits \& services vs. education

\begin{tabular}{|l|l|l|l|l|l|l|}
\hline Dimension & Educational Background & $\mathrm{n}$ & Mean Rank & Chi-square & P-Value & Decision \\
\hline \multirow{2}{*}{$\begin{array}{l}\text { Opinion on Fringe } \\
\text { Benefits }\end{array}$} & Degree & 71 & 223.37 & 11.122 & 0.004 & Significant \\
\cline { 2 - 4 } & PG & 275 & 186.33 & & \\
\cline { 2 - 4 } & Technical & 34 & 155.54 & & \\
\hline \multirow{2}{*}{$\begin{array}{l}\text { Other Benefits \& } \\
\text { Services }\end{array}$} & Degree & 71 & 161.12 & \multirow{2}{*}{7.829} & 0.02 & Significant \\
\cline { 2 - 4 } & PG & 275 & 194.57 & & & \\
\cline { 2 - 4 } & Technical & 34 & 218.91 & & \\
\hline
\end{tabular}

Table no.2.22 furnishes about the mean difference of opinion scores of the respondents on fringe benefits and other benefits and services with regard to educational qualification. It is concluded from the above table that, the mean ranks of the three categories of educational backgrounds for fringe benefits and other benefits and services are significantly differ as per the significant P-values of the Kruskal Wallis\& H-statistic maintained above. Further their opinion is not unanimous at 5\% level of significance. Regarding fringe benefits the degree respondents gave more positive opinion (223.37). For other benefits and services technical respondents gave positive opinion (218.91).

\section{Mann-Whitney U-test}

Table No.2.23: Respondents' opinion on fringe benefits and other benefits \& services vs. gender

\begin{tabular}{|l|l|l|l|l|l|l|l|}
\hline Dimension & Gender & $\mathrm{n}$ & Mean Rank & Sum of Ranks & Mann-Whitney U & P-Value & Decision \\
\hline $\begin{array}{l}\text { Opinion on Fringe } \\
\text { Benefits }\end{array}$ & Male & 335 & 188.56 & 63167.00 & 6887 & 0.000 & Significant \\
\cline { 2 - 8 } & Female & 45 & 204.96 & 9223.00 & & & \\
\hline $\begin{array}{l}\text { Other Benefits \& } \\
\text { Services }\end{array}$ & Male & 335 & 185.53 & 62153.00 & 5873.000 & 0.015 & Significant \\
\cline { 2 - 5 } & Female & 45 & 227.49 & 10237.00 & & & \\
\hline
\end{tabular}

The P-values of the Mann-Whitney U-statistic for the dimension fringe benefits and other benefits and services are statistically significant i.e whatever may be the gender the response given by them is not similar to each other. Female respondents given more optimistic opinion for both dimensions rather than the male respondents as per the higher mean ranks observed from the above table no.2.23.

Table No.2.24: Respondents' opinion on fringe benefits and other benefits \& services vs. marital status

\begin{tabular}{|l|l|l|l|l|l|l|l|}
\hline Dimension & Marital Status & $\mathrm{n}$ & Mean Rank & Sum of Ranks & Mann-Whitney U & P-Value & Decision \\
\hline $\begin{array}{l}\text { Opinion on Fringe } \\
\text { Benefits }\end{array}$ & Unmarried & 123 & 157.40 & 19360.00 & 11734 & 0.000 & Significant \\
\cline { 2 - 5 } & Married & 257 & 206.34 & 53030.00 & & & \\
\hline $\begin{array}{l}\text { Other Benefits \& } \\
\text { Services }\end{array}$ & Unmarried & 123 & 178.67 & 21977.00 & 14351 & 0.144 & Not Significant \\
\cline { 2 - 5 } & Married & 257 & 196.16 & 50413.00 & & & \\
\hline
\end{tabular}

Marital status from the above table no.2.24 reveals that there is a significant mean difference in the opinion score between the unmarried and married respondents with respect to the dimension fringe benefits. Whereas there is no significant mean difference between the marital status with regard to other benefits and services. Marital status has no impact on their opinion on the dimension other benefits and services. Further the mean value ranks 206.34 and 196.14 of the married respondents are high for the fringe benefits and other benefits and services respectively.

\section{References}

[1]. U.S.A. Department of Labour, 'Glossary of Current Industrial Relations \& Wage terms’, Bulliten No.1438, 1968, pp. 32-33. 